\title{
Relationship between neoathyreus sp and weather
}

\begin{abstract}
Study the meteorological factors is important to understand Neoathyreus sp population dynamics. So this study examined the relationship between meteorological conditions and the Neoathyreus sp population fluctuation in Cocal Mata in Teresina-PI city, Brazil, from August 2011 to July 2012. Neoathyreus sp were collected weekly in 12 pitfall traps unattractive. During the period analyzed only in the months of February to April of 2012 was registered the presence of this species. There was a significant and negative association between the registration of the population fluctuation to the insolation $(\mathrm{r}=-0.61$; $\mathrm{p}$-value $<$ $0.05)$ and the average temperature of the compensated air $(r=-0.55 ; \mathrm{p}$-value $<0.10)$ and positive to the pluviometric precipitation $(\mathrm{r}=0.69$; $\mathrm{p}$-value $<0.05)$. Thus it was evidenced that there is species seasonality associated with Cocal Mata.
\end{abstract}

Volume 2 Issue 3 - 2018

\author{
Marcos Paulo Gomes Gonçalves \\ Center of Agricultural Sciences, Federal University of Piauí, \\ Brazil \\ Correspondence: Marcos Paulo Gomes Gonçalves, Center \\ of Agricultural Sciences, Federal University of Piauí, Teresina, PI, \\ Brazil, Email mpgg1988@gmail.com
}

Received: January 22, 2018 | Published: June 12, 2018

Keywords: biometeorology, entomology, ecohydrology

\section{Introduction}

The insects Neoathyreus sp belongs to the family Bolboceratidae and are popularly known as beetles. Also are important environmental indicators, due to the occurrence in quantity and diversity of habitats that occupy. Costa ${ }^{1}$ reports its occurrence: in the soil, in the plants, in the waters of rivers, in the streams and in the marine beaches; Paiva ${ }^{2}$ studied its association with biotic factors, relation with vegetables, and abiotic factors, such as temperature, air humidity, pluviometric precipition and photoperiod, as well as soil conditions, among others. According Gomes Gonçalves ${ }^{3}$ the beetles like all living beings are subject the nature forces. Being able negatively influence or to facilitate the development of certain species. Thus Study the meteorological factors is important to understand Neoathyreus $s p$ population dynamics. For being a relevant and for complement the existing studies with the species Neoathyreus sp, the objective was to analyze the relationship of sunshine, pluviometric precipiton, average air temperature and relative humidity in the population fluctuation of Neoathyreus sp in Cocal Mata.

\section{Methodology}

This study was carried out in a native vegetation area, latitude and longitude of $5^{\circ} 2^{\prime}$ ' $52^{\prime}$ ' $\mathrm{S}$ and $42^{\circ} 47^{\prime}$ ' 11', typical of cocal vegetation, in the region of Teresina-PI, Brazil. For the collection, twelve pitfall traps were used, with no attraction. They are used in the capture of ground animals. Each trap made of plastic had capacity of $500 \mathrm{~mL}$, diameter of $10 \mathrm{~cm}$ and height of $11 \mathrm{~cm}$. They received a cover of a $20 \mathrm{~cm}$ diameter plastic dish, suspended by pieces of wood approximately $15 \mathrm{~cm}$, to prevent or reduce the entry of water during the rainy season. The traps were buried with the border at ground level and in each was added $200 \mathrm{~mL}$ of $4 \%$ formaldehyde solution as fixative liquid. It collection were carried out weekly from August 2011 to July 2012.

The monthly meteorological data on insolation, the relative humidity of the compensated air, the average temperature of the compensated air and the pluviometric precipition were obtained through the National Institute of Meteorology- INMET network, Table 1. The meteorological data were recorded in the weather station that has latitude and longitude of $5^{\circ} 2^{\prime} 5^{\prime} \mathrm{S}$ and $42^{\circ} 48^{\prime} 5^{\prime \prime} \mathrm{W}$ and an altitude of $75 \mathrm{~m}$. The native forest area, in which the samples were obtained, is within a $3 \mathrm{~km}$ radius of said meteorological station. The correlation between beetles and meteorological elements was calculated by Pearson's linear method by BioEstat software version 5.3. ${ }^{4}$

Table I Monthly records of the population fluctuation of Neoathyreus sp sampled in the Cocal Mata in the municipality of Teresina-PI from August $20 \mathrm{II}$ to July 2012

\begin{tabular}{llllllllllllll}
\hline \multirow{2}{*}{ Specie } & 2011 & \multicolumn{10}{c}{2012} & & \multicolumn{1}{c}{} \\
\cline { 2 - 12 } & Aug. & Sept. & Oct. & Nov. & Dec. & Jan. & Feb. & Mar. & Apr. & May. & June & July & Total \\
\hline Neoathyreus sp & - & - & - & - & - & - & 13 & I & I & - & - & - & 15 \\
\hline
\end{tabular}

\section{Results and discussion}

During the period from August 1, 2011 to July 31, 2012 in the municipality of Teresina, there was average insolation of $8.41 \mathrm{~h} / \mathrm{d}$, average relative humidity of the compensated air of $72.44 \%$, mean air temperature compensated daily of $27.37^{\circ} \mathrm{C}$ and $1218.9 \mathrm{~mm}$ of pluviometric precition. According to Table 2 in the analyzed period were collected 15 insects of the species Neoathyreus sp. The population peak occurred in February 2012, when 12 specimens were collected. Only was collected Neoathyreus sp in the period from February to

April 2012. According to Table 3 population fluctuation Neoathyreus $s p$ was significantly correlated to pluviometric precipition $(\mathrm{r}=0.69$, $\mathrm{p}$-value $<0.05)$ and mean air temperature $(\mathrm{r}=-0.55 ; \mathrm{p}$-value $<0.10)$ and insolation $(r=-0.61 ; p$-value $<0.05)$. Regarding the relative humidity of the compensated air, there was no significant correlation, $\mathrm{p}$-value $>$ 0.10 . The results found in the present study corroborate with Rech et al., ${ }^{5}$ who observed seasonal distribution of beetle families, which are influenced by climatic variables and food availability. Also Paiva ${ }^{2}$ verified population fluctuation of beetles is affected by the climatic variables of the region whose presence is seasonal and conditioned 
by climatic parameters. It is observed that the individuals of the identified species occupy a functional position or biological position within the ecosystem in which they are inserted. According to Gomes Gonçalves $^{3}$ this comprises what the specimens represent in the overall picture of the ecosystem, what they do and how they do it. Browne \& Scholtz ${ }^{6}$ describe that most species of the Bolboceratidae family dig holes to lay their eggs. According to the same authors bolboceratids are typically detritivores, feeding on matter of vegetal or animal origin decomposed and their adults form nests of litter (often moldy); however there are species that lay their eggs in or on the fecal mass, which later the larvae feed on. According to Gomes Gonçalves ${ }^{3}$ all the physical and biological entities of a given ecosystem form a single unified and complex integral system. As seen there is a deep, direct and essential linkage of the beetles identified with the ecological processes of the ecosystem in which they are inserted. Given this important it is necessary to remain in the environment. That is why there must be maintenance of the meteorological conditions and the preservation of the Cocal Mata.

Table 2 Weather data (average insolation, relative average air humidity, pluviometric precipitacion and average air temperature), from August I, 20 I I to July $3 \mathrm{I}, 20 \mathrm{I}$, in the city of Teresina-Piauí

\begin{tabular}{llllll}
\hline Year & Month & $\begin{array}{l}\text { Insolation } \\
(\text { h.d-I) }\end{array}$ & $\begin{array}{l}\text { Relative average air } \\
\text { humidity }(\%)\end{array}$ & Precipitacion $(\mathbf{m m})$ & $\begin{array}{l}\text { Average air } \\
\text { temperature }\left({ }^{\circ} \mathbf{C}\right)\end{array}$ \\
\hline \multirow{2}{*}{2011} & August & 10.1 & 65.4 & 10.8 & 27.2 \\
& September & 10.3 & 58.1 & 0.6 & 28.5 \\
& OctOber & 8.8 & 66.1 & 167.6 & 28.6 \\
& November & 7.8 & 74.8 & 124.6 & 27.4 \\
& December & 8.6 & 68.2 & 23.4 & 28.3 \\
\hline \multirow{2}{*}{2012} & January & 6.4 & 75.7 & 133.1 & 27.1 \\
& February & 5.6 & 83.4 & 317.1 & 26.2 \\
& March & 7.4 & 85 & 264 & 26.3 \\
& April & 7.7 & 82.5 & 121 & 26.7 \\
& May & 9.3 & 77.3 & 31.3 & 27.2 \\
& June & 8.8 & 72.7 & 25.4 & 27.2 \\
& July & 10 & 60.8 & 0 & 27.5 \\
\hline
\end{tabular}

Source: INMET Network Data

Table 3 Correlation between the monthly occurrence records of the Neoathyreus sp population fluctuation and the monthly meteorological data

\begin{tabular}{|c|c|c|c|c|c|c|c|c|}
\hline \multirow[b]{3}{*}{ Specie } & \multicolumn{2}{|c|}{ Insolation } & \multicolumn{2}{|c|}{ Relative average air humidity } & \multicolumn{2}{|c|}{ Precipitacion } & \multicolumn{2}{|c|}{ Temperature } \\
\hline & $(r)$ & p- value & $(\mathbf{r})$ & p-value & $(\mathbf{r})$ & p-value & (r) & $\begin{array}{l}\mathrm{p}- \\
\text { value }\end{array}$ \\
\hline & & & & & & & & \\
\hline Neoathyreus sp & $-0,61$ & $<0,05$ & 0,49 & $>0,10$ & 0,69 & $<0,05$ & $-0,55$ & $<0,10$ \\
\hline
\end{tabular}

Normality $=12$, Freedom Degrees $=10$

\section{Conclusion}

Only was collected Neoathyreus $s p$ in the period from February to April 2012. There was a significant and negative association between the registration of the population fluctuation to the insolation and the average temperature of the compensated air and positive to the pluviometric precipitation. That there is species seasonality associated with Cocal Mata.

\section{Acknowledgements}

None.

\section{Conflict of interest}

The author declares there is no conflict of interest.

\section{References}

1. Costa C, Coleoptera. Biodiversidade do Estado de São Paulo. Brasil: síntese do conhecimento ao final do século XX. In: Joly CA, Bicudo
CEM, editors. Invertebrados terrestres. São Paulo: Museu de Zoologia da Universidade de São Paulo. 1999.

2. Paiva DR. Escarabeineos (coleoptera: scarabaeidae) associados a diferentes sistemas de manejo de pastagens no município de teresinaPI. Dissertação (Mestrado em Agronomia: Produção vegetal), Universidade Federal do Piauí. 2009;1-56.

3. Gomes Goncalves Marcos Paulo. Relação Entre Tempo e Besouros em Mata de Cocal. Rev bras meteorol São Paulo. 2017;32(4):543-554.

4. Ayres M, Ayres JRM, Ayres DL, et al. BioEstat: aplicações estatísticas nas áreas das ciências biológicas e médicas. Belém: Publicações Avulsas Mamirauá. 2007.

5. Rech T, Oliveira RC de. Biodiversidade e flutuação populacional de coleópteros em fragmento florestal em cascavel, PR. Céu Azul. FAG. 2007;12.

6. Browne DJ, Scholtz CH. Phylogeny of the families of the Scarabaeiodea (Coleoptera) based on characters of the 552 Gonçalves. hindwing articulation, hindwing base and wing venation. Systematic Entomology. $1995 ; 21: 145-173$. 